\title{
International Students' Satisfaction with the Services of Agriculture Bank of China
}

\author{
Robert Brenya*, Weijun Cui \\ School of Business, Nanjing University of Information Science and Technology, Nanjing, China \\ Email: ^brenyarobert@yahoo.com, 000928@nuist.edu.cn
}

How to cite this paper: Brenya, R., \& Cui, W. J. (2018). International Students' Satisfaction with the Services of Agriculture Bank of China. Chinese Studies, 7, 230-241. https://doi.org/10.4236/chnstd.2018.73020

Received: July 5, 2018

Accepted: August 7, 2018

Published: August 10, 2018

Copyright () 2018 by authors and Scientific Research Publishing Inc. This work is licensed under the Creative Commons Attribution International License (CC BY 4.0).

http://creativecommons.org/licenses/by/4.0/

\begin{abstract}
Service satisfaction improvement of customers is the present way most industries conduct every trade. Banks are no exception from this revolution. Customers' preference has become a necessary module of business strategy in financial institutions. This research is related to international students' satisfaction with the services of Agriculture Bank of China. The study used the quantitative method and the unit was the international students who are customers of Agriculture Bank of China. The primary data was derived from a well-structured questionnaire that was administered through QuestionPro online software and the secondary data came from the bank website, journals and existing literature. STATA statistical tool was used in the data analysis, interpretation, tabulation and graphical representation of the study. It preserves a lot of time as commands were type instead of searching for it from the menu tab. Among the factors, the assurance, responsiveness, reliability, etc. were investigated. From the result, Agriculture Bank of China provides satisfactory services to the international students' customers. However, the study recommended more innovative ways of curbing the language barrier, the long channel of opening an account and the like. Despite challenges faced by the researcher, the study was carried out successfully.
\end{abstract}

\section{Keywords}

ABC Bank, International Students, Satisfaction, Services, China

\section{Introduction}

Banking industries today in the People's Republic of China is growing massively in financial transactions. Institutions ability to enhance growth in moderate and global banking services are consistently changing the approach of doing business 
with customers, whom without fail expecting good quality of services and more conveniences (Rubogora, 2017). Nesrin et al. (2016) asserted that institutions with great customer satisfaction have more future profitability. Aksoy et al. (2008) show that institutions with enhancement in customer satisfaction have higher future estimations. Banks are improving their data and enhancing their operations to suit customers' preferences. Moreover, services are continuously being upgraded to provide an enriching experience to the customers (Jamal, 2003; Lee, 2009). Customer service is the undeniable term that describes the broad mixture of systems and grows in every financial industry and best client relationships that promote business. Basically, customers are the crucial component to keep a business running (Nguyen et al., 2007). Sometimes services rendered by some banks create dissatisfaction on consumers due to inadequate quality (Nimako \& Mensah, 2014). As a result, Agricultural Bank of China has upgraded its service and is generally accepted by all. Various institutions across the provinces of China patronized the banking products and services of $A B C$ Bank. The bank acknowledges that the financial industry is being thoroughly refurbished by technology, so they too need to upgrade their services and products. The banking industry has developed from conventional methods of banking to Internet banking and is therefore possible of accomplishing every objective, depending on the mechanism put in place. It is therefore not surprising that greater recognition and attention are now being given to financial industries.

\section{Problem Statement}

The products and services of Agriculture Bank of China have been much appreciated by its locality. As stated from the camp of (Anderson \& Fornell, 2000), customer's conclusion goes a long way to have a positive or negative impact on the institution as a whole. Considering the nature of international students living in China and the difficulties such as language barrier, consistent visa regulatory policies and the like they face when transacting businesses with Agriculture Bank of China. It is for these reasons that an academic study is needed to check how the service quality of $\mathrm{ABC}$ Bank will improve the level of satisfaction of International students' satisfaction. Kottler, (2000), postulated that satisfaction is a person's displeasure resulting from comparing the product's perceived outcome to his or her expectations.

Research Objective;

\section{General objective}

To determine the efficiency and effectiveness of $A B C$ 's products and services quality on international customer satisfaction.

Specific objectives

- To determine the level of products and service quality in Agriculture Bank of China

- To determine the level of customer satisfaction in Agriculture Bank of China.

- To determine the relationship between service quality and customers' satis- 
faction development.

\section{Literature Review}

\subsection{The Concept of Customer Satisfaction}

In a viable financial institution where businesses compete for customers, customer satisfaction is seen as a key differentiator (Rubogora, 2017) and increasingly become a key commodity in decision making (Fornell, Rust, \& Dekimpe, 2010; Hui, Wan, \& Ho, 2007; Hume \& Mort, 2008). Institutions have to bring forth innovative ideas to beat competitions as well as increasing the needs of customers (Cavusgil et al., 2003). The degree to which the customer is happy depends on the numerous services they received. Prior studies suggest that customer involvement seems to be closely related to satisfaction, (Dellande, Gilly, \& Graham, 2004; Grissemann \& Stokburger-Sauer, 2012) and/or influences customers' perceptions of a service experience (Edvardsson, 2005). According to (Franke, Keinz, \& Steger, 2009), customers with high product connection, participate more in a continuity of that particular products. Therefore, customer satisfaction is the probable element which banks use to gain a tactical advantage over other financial institutions. Customer satisfaction is the groundwork for any institute to keep its existing customers (Khan, 2012). Banks make policies to maintain their old customers because the cost involves in getting new ones are high. Besides loyal customers are reluctant to risk their relationship with an institution, which is a reason for customers not complain; (Mittal, Huppertz, \& Khare, 2008). Customers react differently to what they anticipate and what they receive, regarding the fulfillment of needs, goals and/or desires from the environment (Deci et al., 2001). Existing literature shows that customers share their experience with their colleagues and spread the information quickly when they have had a bad experience with a financial institution (Nimako \& Mensah, 2014). Banks are aware of the essence in improving both products and services of customers which leads to satisfaction. As the service qualities exceed customer's prior expectations, it's easily influence them, (Bus et al., 2018). According to (Hansemark \& Albinson, 2004), "what customers expect from their service providers is their satisfaction; as services cannot be separated from its provider, (Rubogora, 2017) as a result, banks that fail to build the strong bond with it customers loose on customer loyalty (McEwen, 2005). The going concern of a bank has small worth without the existence of the customer. International students in the People's Republic of China have a wide range of banks selecting choice. So the bank main duty is not to win customers but to retain them through effective customer service.

\subsection{Service Quality and Satisfaction Development}

As quality is a relevant option that customers use to distinguish between services offered by different institutions. The person or institution that procure the goods and services of another (Bus et al., 2018), wants the best output from the trans- 
action. Every business institution needs to consider the abstract nature of customer satisfaction and providing quality services helps maintain and develop good relation (Brenya et al., 2018). Customers are the lifeblood of every business and their service satisfaction is necessary for the institution growth. The relation between a customer and an institution affects customers' reactions to failures (Magnini et al., 2007). Customer satisfaction development requires a smooth relationship between the bank and its customers. Even though, sometimes some banks prevent their staff relation with customers because of they think the relationship might divert the loyalty of customers, (Bendapudi \& Robert, 2002; Palmatier, Scheer, \& Steenkamp, 2007). A well-developed customer satisfaction increases their desires to transact business, (Nesrin et al. 2016). The bank must acknowledge the customer progress through generating and providing value for money services. Banks that really want to develop their customer satisfaction laid down measures that best recognize and improve the going concern relationship with the customers (Latif, 2017).

\subsection{Level of Customer Satisfaction}

Ibojo et al., (2013) asserted that, for an institute to persistently keep its customers in this competitive industry, there is the need for a tactical approach to satisfying the needs of the customers. One of the aims of the research is to determine the level of customer satisfaction with the service of Agriculture Bank of China. The satisfaction was measured using five Likert scaled subjects ranging between one and five; such as 1 = highly satisfied, 2 = Somewhat Satisfied, $3=$ Neutral, 4 $=$ somewhat dissatisfied and $5=$ highly dissatisfied. Evidence from Table 2 indicates we can conclude that the customer satisfied is above average which is very good for the business because it tells us where the customer loyalty rest. And possibly their recommendations the bank activities to other people.

\section{Research Design and Research Methodology}

\subsection{Research Design}

In every study, there is the blueprint which specifies the structure of the research design. Research design entails the qualitative and quantitative research. According to (Malhotra \& Birks, 2006), qualitative research is usually unstructured, aspire for discovery and it also deals with fine art such as narratives, descriptions, pictures and the like whiles quantitative research emanate through well layout questionnaires and interviews. Quantitative data quantify unprocessed information to be measured through statistical means and data is obtained from a target population. The aim of the study is to use quantitative research. The study used international student leaving in Nanjing City who are customers of ABC bank. The total sample of four hundred and one (401) of the total population of Agriculture bank of China international customers and the questionnaires were randomly given to international students who transact business with the bank. 


\subsection{Research Methodology}

Probability sampling method was used in the research where primary and secondary data was also used in the analysis of the study. The primary source from the well-structured questionnaires administered to the international students' and the secondary data obtained from the internet, unpublished articles, journal, staff from the Pancheng Branch and the like. The questionnaire was the main source of data of which it was collected through an application called QuestionPro which made easy in answering the questions of the researcher. The demographic data such as the age, gender and the like, customer satisfaction of products and service of the bank such as employee's reliability, quick response to customer's plight was captured in the questionnaire. A closed-end Likert scale-typed questionnaire was administered making it easy for the respondent to select answers such as Strongly agree, Agree, Neutral, Disagree and Strongly disagree and other aspects such as Highly satisfied, Somewhat satisfied, Neutral, Somewhat Dissatisfied and Highly dissatisfied. The study used STATA analytical tool in the presentation and interpretation of data. According to (Shamoo \& Resnik, 2003), various analytical procedures endow with ways of deducing information from data and separating the irrelevant materials. STATA enables it to be seen clearly in a graphical form. STATA preserves a lot of time trying to look for a command from the menu if you can type it. Command type can also be saved in the do-file for future use.

\section{Discussion and Evaluation}

\subsection{Demographic Data}

\subsubsection{Gender}

Out of 401 students that answered the questionnaires, a majority of 245 (61.1\%) respondents are male and the remaining 156 respondents representing $38.9 \%$ are female. The information is from Figure 1 below;

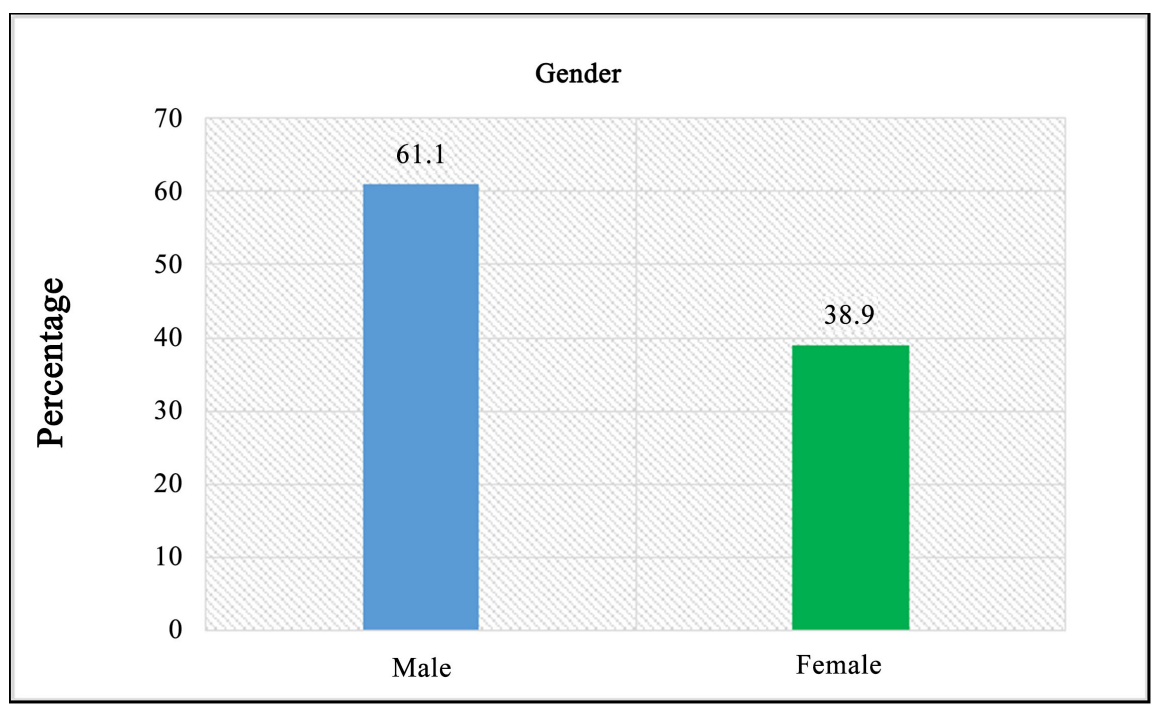

Figure 1. Gender respondents. Source: Field survey 2017. 


\subsubsection{Age}

The research had a youthful age representation since is purposely for students and there is an age limit as you climb the educational ladder. $54.11 \%$ of the respondents are in the age category of 18 and 25 years. $34.66 \%$ of total respondents fall under 26 to 33 years, 41 respondents representing $10.22 \%$ are between 34 and 40 years and only $1 \%$ represent 41 years and above. The information is from Figure 2.

\subsubsection{Marital Status}

Majority of the respondents were single and it carried $82.79 \%$ out of 401 respondents, 64 responded married representing $15.96 \%$ and $1.25 \%$ are under divorce/widow. The information is from Figure 3.

\subsubsection{Universities Attended}

Information from Table 1 indicates $4.74 \%$ (19) of the students who responded to the questionnaires were from Nanjing Medical University (NMU), from the camp of Nanjing Pharmaceutical University we had 3 students indicating $0.75 \%$, $5.74 \%$ (23) of the responses also came from Nanjing University of Science and Technology (NJUST). Most of the respondents came from Nanjing University of Information Science and Technology with a greater number of 230 students representing $57.36 \%$ of the total population. Southeast University students also contributed with 17 respondents showing $4.24 \%$. The opportunity was given to all other universities to participate in the collection of data and this yielded 109 responses from other universities students from Nanjing Technology University, Nanjing Medical University and the like indicating $27.18 \%$ of the total respondent. The information is from Table 1.

\subsection{Service Quality and Customer Satisfaction}

\subsubsection{Assurance}

The responses below indicate that employees are very well trained and customers feel safe in doing business with the bank. $17.71 \%$ (71) strongly agree with the statement, whereas 211 respondent representing $52.62 \%$ agree with the statement. Some of the respondents feel undecided, 27.43\% (110) respondent were neutral. On the other hand, 7 respondent disagree and 2 strongly disagree with employees are much trained and you feel safe doing business with the bank; and this indicates $1.75 \%$ and $0.5 \%$ respectively. Customers feel confidence in working with the bank.

\subsubsection{Responsiveness}

As depicted in Table 2, 57 (14.21\%) respondents strongly agree with the facts that, $\mathrm{ABC}$ bank inform its customers as to when banking service begins and quick services to customers. 215 response representing $53.62 \%$ agree with the statement followed by $25.94 \%$ (104) who have no stands in the matter (neutral). 21 (5.24\%) disagree and only $1 \%$ (4), strongly disagree with the matter. Customers feel positive from the employees. 
Table 1. University respondents.

\begin{tabular}{cccc}
\hline University & Freq. & Percent & Cum. \\
\hline NMU & 19 & 4.74 & 4.47 \\
NPU & 3 & 0.75 & 5.49 \\
NJUST & 23 & 5.74 & 11.22 \\
NUIST & 230 & 57.36 & 68.58 \\
SEU & 17 & 4.24 & 72.82 \\
OTHERS & 109 & 27.18 & 100 \\
Total & 401 & 100 & \\
\hline
\end{tabular}

Source: Field survey 2017.

Table 2. Service quality and customer satisfaction rating.

\begin{tabular}{|c|c|c|c|c|c|c|c|c|}
\hline Variables & $\begin{array}{l}\text { Number of } \\
\text { Respondent }\end{array}$ & & Level & Of & Percent & (\%) & Mean & $\begin{array}{l}\text { Standard } \\
\text { Deviation }\end{array}$ \\
\hline & & $\begin{array}{c}\text { Strongly } \\
\text { Agree }\end{array}$ & Agree & Neutral & Disagree & $\begin{array}{l}\text { Strongly } \\
\text { Disagree }\end{array}$ & & \\
\hline Assurance & 401 & 17.71 & 52.62 & 27.43 & 1.75 & 0.5 & 2.147132 & 0.7387814 \\
\hline Responsiveness & 401 & 14.21 & 53.62 & 25.94 & 5.24 & 1 & 2.25187 & 0.7993139 \\
\hline Reliability & 401 & 13.47 & 46.88 & 34.16 & 4.99 & 0.5 & 2.321696 & 0.7866086 \\
\hline Empathy & 401 & 19.7 & 52.37 & 24.69 & 2.74 & 0.5 & 2.119701 & 0.7652685 \\
\hline Materials & 401 & 32.92 & 49.63 & 15.71 & 1.5 & 0.25 & 1.865337 & 0.7428462 \\
\hline Services & 401 & 18.95 & 46.38 & 28.43 & 5.24 & 1 & 2.229426 & 0.8498423 \\
\hline Products & 401 & 17.71 & 48.38 & 29.68 & 2.24 & 2 & 2.224439 & 0.8333674 \\
\hline
\end{tabular}

Source: Field survey 2017.

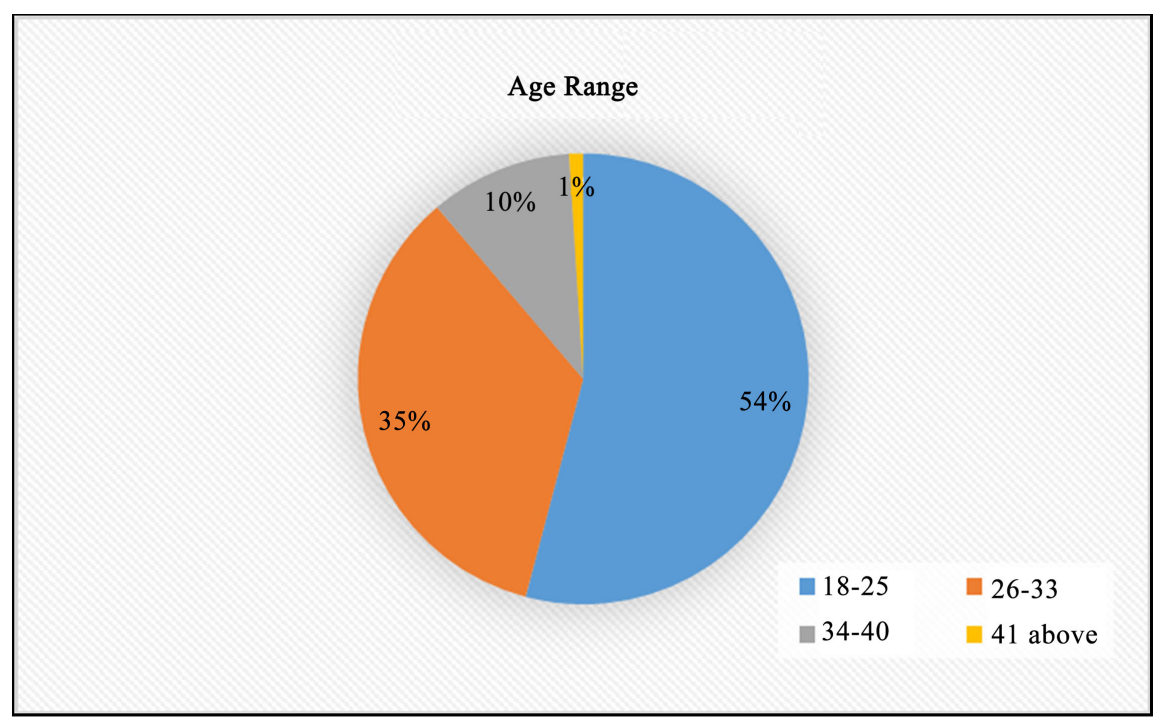

Figure 2. Age range respondents. Source: Field survey 2017. 


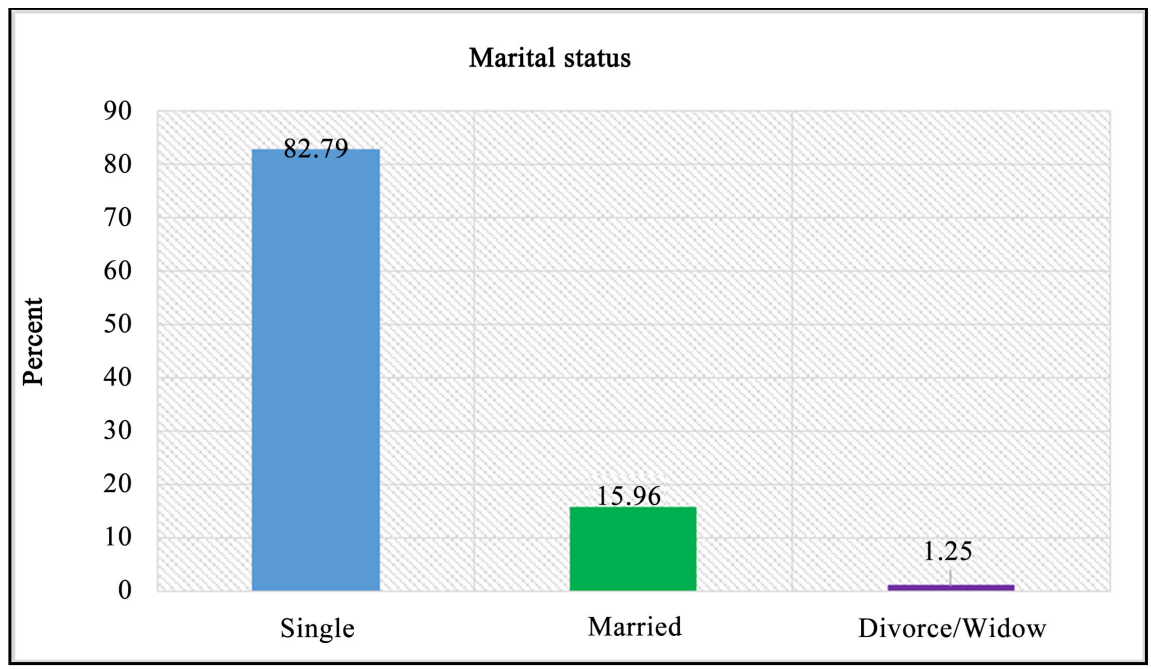

Figure 3. Marital status respondents. Source: Field survey 2017.

\subsubsection{Reliability}

54 count from the respondents indicating $13.47 \%$ strongly agree with the statement, the bank delivering error-free service on time and reliable in handling customers' service problems. $46.88 \%$ (188) from the table below-representing majority of the respondents Agree to the below statement. This followed by 137 (34.16\%) respondents who either think the bank delivery is error-free or made up of errors. However, 20 respondents disagree with the statement as well as 2 respondents strongly disagree with the statement representing $4.99 \%$ and $0.5 \%$ respectively.

\subsubsection{Empathy}

With reference to Table 2, 19.7\% (79), of customers strongly agree with the fact that bank employee's deal with customers' with care and understanding at a good banking hour. 210 respondents indicating 52.37\% Agree with the statement, 99 (24.69\%) had the neutral ground whiles 11 respondents disagree with $2.74 \%$ and 2 respondents showing $0.5 \%$ strongly agree with the statement.

\subsubsection{Materials}

On the assessment of how the employees dress neat, appear professional and the ability of the bank to use modern equipment, 132 (32.92\%) Strongly agree, 199 (49.63\%) of the responses came from customers who Agree with the statement. 63 respondents indicating $15.71 \%$ cannot decide whether they are for or against the motion. On the other hand, $6(1.5 \%)$ customers disagree and 1 respondent strongly disagree and it represents 0.25 of the total percentage.

\subsubsection{Service}

Every customer needs speedy delivery and a quick response to his or her problems and from the recorded figures 76 respondents representing $18.95 \%$ strongly agree with the statement; the bank instance customer delivery and quick response to customers complain, $186(46.38 \%)$ agree with the statement, 114 res- 
pondents indicating $28.43 \%$ are on the neutral grounds whiles 21 responded Disagreement and 4 strongly disagreement indicating $5.24 \%$ and $1 \%$ respectively.

\subsubsection{Product}

From the table or figure or diagram provided below, there is $17.71 \%$ (71) of customers who strongly agree with the fact that; the bank products are designed to suit customer choice and can be used easily. Indeed the figures go to show that 194 respondent (customers) showing 48.38\% Agree with the statement and 29.68\% (119) had the neutral decision. However, 9 (2.24\%) customers strongly disagree and 8 (2\%) disagrees.

\section{Conclusion and Recommendation}

\subsection{Conclusion}

The relevant of service delivery increases satisfaction, retains customers and excels in sales of bank products and services. Services such as the customer ability to take money from any bank branch in China, error-free service delivery, quick response to customer's plight, electronic SMS alert which discloses the debit and/or credit balances of the customer and the like. The study on international students of ABC Bank was guided by the following objectives: To determine the level of products and service quality, the level of customer satisfaction and the relationship between service quality and customer satisfaction development. The data were analyzed using STATA's descriptive statistics. The STATA application used assessed the satisfaction in the area of assurance, responsiveness, reliability, empathy, materiality, services, and products. This proved the performance of the Agricultural Bank of China services to international students has been positive and triumphant. The bank's ability to identify customer's needs and providing them was crucial to the development of customer relations that at the end promote marketing of their products (Latif, 2017). From the customers, the bank shows the good response to their plight and provides them with good and satisfactory services.

\subsection{Recommendations}

The suggestions are based on the study's objectives and will increase customer's satisfaction and services if followed by Agricultural Bank of China as well as Chinese banking industry. Below are the highlighted recommendations; Firstly, Based on the researcher's personal observation, the bank needs more trained staff who are fluent in the English language to communicate with the international customers. Truly, the bank's staff inability to express themselves in English absolutely hurt the feelings of foreign customer's satisfaction and their appreciation towards service quality. Secondly, the management of Agriculture Bank of China should conduct regular marketing research studies on their own customers to determine their demographic data and other related profiles of customers. This will enable the bank to make informed decisions about interna- 
tional customer's needs. Also, Agriculture Bank of China management should be frequently be updated with the new products and services being demanded by foreigners in the country. It helps strengthen social interaction, as customers will be more motivated to tell about products and services experience they feel satisfied them (Lam \& So, 2013). Base on the fact that, the research was focused only the international students studying in the People's Republic of China, the same study should be replicated by the using the Chinese citizens us the respondents to know the complete satisfactory level of customers.

\section{Acknowledgements}

This research has come to the realization through the unreserved support of International students in Nanjing, China.

\section{Declaration Interest Statement}

I, Robert Brenya, wish to declare that this research paper was derive from final year thesis and has never been submitted in any journal for the purpose of publication and that; the paper is presented with the consent of my co-author. Works by other author, which served as a source of information, have been duly acknowledged. There is NO COMPETING INTERESTS.

\section{Funding}

This research did not receive any specific grant from funding agencies in the public, commercial, or not-for-profit sectors.

\section{References}

Aksoy, L., Groening, C., Keiningham, T. L., \& Yalcin, A. (2008). The Long-Term Stock Market Valuation of Customer Satisfaction. Journal of Marketing, 72, 105-122.

Anderson, E. W., \& Fornell, C., (2000). Foundations of the American Customer Satisfaction Index. Total Quality Management, 11, 869-882.

Bendapudi, N., \& Robert, P. L. (2002). Managing Business-to-Business Customer Relationships Following Key Contact Employee Turnover in a Vendor Firm. Journal of Marketing, 66, 83-101.

Brenya, R. et al. (2018). Factors Affecting the Academic Staff and Their Impact on the University: A Case Study of NUIST. Educational Research International, 71-82.

Bus, A. J., Review, M., Study, A. C., \& Dawro, T. (2018). Assessment of the Factors that Affect Customer Satisfaction on Service Quality: A Case Study in Ethio Telecom Dawro Zone. Arabian Journal of Business, 8, 1-5.

Cavusgil, S. T., Calantone, R. J., \& Zhao, Y. (2003). Tacit Knowledge Transfer and Firm Innovation Capability. Journal of Business \& Industrial Marketing, 18, 6-21.

Dellande, S., Gilly, M. C., \& Graham, J. L. (2004). Gaining Compliance and Losing Weight: The Role of the Service Provider in Health Care Services. Journal of Marketing, 68, 78-91.

Fornell, C., Rust, R. T., \& Dekimpe, M. G. (2010). The Effect of Customer Satisfaction on Consumer Spending Growth. Journal of Marketing Research, 47, 28-35. 
Franke, N., Keinz, P., \& Steger, C. J. (2009). Testing the Value of Customization: When Do Customers Really Prefer Products Tailored to Their Preferences? Journal of Marketing, 73, 103-121.

Grissemann, U. S., \& Stockburger-Sauer, N. E. (2012). Customer Co-Creation of Travel Services: The Role of Company Support and Customer Satisfaction with the Co-Creation Performance. Tourism Management, 33, 1483-1492.

Hansemark, O. C., \& Albinson, M. (2014). Customer Satisfaction and Retention: The Experiences of Individual Employees. Managing Service Quality, 14, 40-57.

Hui, T. K., Wan, D., \& Ho, A. (2007). Tourists' Satisfaction, Recommendation and Revisiting Singapore. Tourism Management, 28, 965-975.

Hume, M., \& Mort, G. S. (2008). Satisfaction in Performing Arts: The Role of Value? European Journal of Marketing, 42, 311-326.

Ibojo, B. O., Olawepo, G. T., \& Akinruwa, T. E. (2013). Effect of Customer Satisfaction on Organizational Profitability, Using an Organization in the Food and Beverage Industry. International Journal of Management Sciences, 1, 159-166.

Khan, I. (2012). Impact of Customers' Satisfaction and Customers' Retention on Customer Loyalty. International Journal of Scientific and Technology Research, 1.

Kottler, P. (2000). Marketing Management (10th ed.). Upper Saddle River, NJ: Prentice Hall.

Lam, D., \& So, A. (2013). Do Happy Tourists Spread More Word-of-Mouth? The Mediating Role of Life Satisfaction. Annals of Tourism Research, 43, 624-650.

Latif, A. A. (2017). Impact of Service Quality on Customer Satisfaction. Australian Journal of Basic, 11, 20-28.

Magnini, V. P., Ford, J. B., Markowski, E. P., \& Honeycutt (2007). The Service Recovery Paradox: The Justifiable Theory or Smoldering Myth? Journal of Services Marketing, 21, 213-225.

McEwen, W. J. (2005). Married to the Brand: Why Consumers Bond with Some Brands for Life. Princeton, NJ: Gallup Press.

Mittal, V., Huppertz, J. W., \& Khare, A. (2008). Customer Complaining: The Role of Tie Strength and Information Control. Journal of Retailing, 84, 195-204.

Nesrin, O. et al. (2016). Customer Satisfaction in the Banking Sector: The Case of North Cyprus. Procedia Economics and Finance, 39, 870-878. https://doi.org/10.1016/S2212-5671(16)30247-7

Nguyen, T. H., Sherif, J. S., \& Newby, M. (2007). Strategies for Successful CRM Implementation. Information Management \& Computer Security, 2, 102-115. https://doi.org/10.1108/09685220710748001

Nimako, S. G., \& Mensah, A. F. (2014). Exploring Customer Dissatisfaction/Satisfaction and Complaining Responses among Bank Customers in Ghana. International Journal of Marketing Studies, 6, 58-71. https://doi.org/10.5539/ijms.v6n2p58

Palmatier, R. W., Scheer, L. K., \& Steenkamp, J.-B. E. M. (2007). Customer Loyalty to Whom? Managing the Benefits and Risks of Salesperson-Owned Loyalty. Journal of Marketing Research, 44, 185-199. https://doi.org/10.1509/jmkr.44.2.185

Shamoo, A. E., \& Resnik, B. R. (2003). Responsible Conduct of Research. Oxford: Oxford University Press. 


\section{List of Abbreviation}

ABC: Agriculture Bank of China

NUIST: Nanjing University of Information Science and Technology.

PRC: People's Republic of China

NMU: Nanjing Medical University

NPU: Nanjing Pharmaceutical University

NJUST: Nanjing University of Science and Technology

SEU: Southeast University 